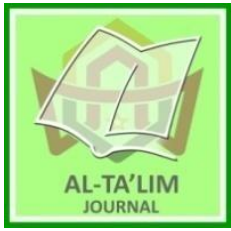

\title{
Enhancing Elementary School Students' Learning Outcomes in the Field of Social Sciences Studies through Problem Based Learning Method
}

Received: $31^{\text {th }}$ April 2019; Revised: 28 ${ }^{\text {th }}$ May 2019; Accepted: $30^{\text {th }}$ July 2019

Permalink/DOI: http: //dx.doi.org/10.15548/jt.v26i2.572

\section{Sita Ratnaningsih*)}

Universitas Islam Negeri Syarif

Hidayatullah Jakarta, Indonesia

E-mail: $\underline{\text { sita@uinjkt.ac.id }}$

\section{Syarif Sumantri}

Universitas Negeri Jakarta, Indonesia.

E-mail: mohamadsumantri@unj.ac.id

\section{Nurjanah}

Universitas Negeri Jakarta, Indonesia.

E-mail: nurjannah@unj.ac.id

\section{Erry Utomo}

Universitas Negeri Jakarta, Indonesia.

E-mail: erryutomo@unj.ac.id

*) Corresponding Author

\begin{abstract}
The learning outcomes of the Social Sciences study at the Elementary School level in Indonesia in general have not shown maximum results, this is because the social studies field includes subjects that are less attractive to students. This study aims to determine the effect of Problem Based Learning learning method and Conventional learning method as well as the ability to think logically towards learning outcomes in Social Sciences. This research was conducted on class VI students of the State Ibtidaiyah Madrasah in Ciputat, with a total of 60 students. This study uses treatment by level $2 \times 2$. The data analysis technique is the analysis of two-way variance (ANAVA). The results of the study showed that: (1) Student learning outcomes in social studies subjects taught using PBL learning method were higher than students taught using conventional method, (2) for students who have high logical thinking skills, the learning outcomes of students taught using the Problem Based Learning method are higher than those taught using conventional method, (3) for students who have low logical thinking skills, student learning outcomes are taught using the PBL method lower than students taught using conventional method.(4) there was an interaction effect between PBL learning method and logical thinking skills.
\end{abstract}

Keywords: Problem based learning method logical thinking ability; social studies learning outcomes

How to Cite: Ningsih, S., Sumantri, M., Nurjanah, N., \& Utomo, E. (2019). Enhancing Elementary School Students' Learning Outcomes in the Field of Social Sciences Studies Through Problem Based Learning Method. Al-Ta Lim Journal, 26(2). doi:http://dx.doi.org/10.15548/jt.v26i2.572

\section{INTRODUCTION}

The interesting problem in social studies learning has been the findings of several studies that social studies learning in schools is often presented in factual forms, concepts that are less meaningful, teachers only pursue the target of achieving the curriculum, do not prioritize the process. Therefore the social studies learning process always tends to be boring. Social studies lessons by students are considered as second grade lessons (Soemantri, 2001), whereas in social studies learning the process is very important (Aziz, Zain, Samsudin, \& Saleh, 2014). In the process of social studies teaching and learning activities, teachers generally deliver teaching material dominated by models and learning media that tend to be conventional which are carried out by teachers of the subject. In this model, the transfer of knowledge occurs in one direction and is only teacher-centered. In addition, the teaching and learning process in social studies is still in the form of a learning process that is 
less attractive to students, learning that is taught tends to be oriented to aspects of knowledge, facts and concepts that are merely memorizing. As a result the dialogical process between students and the material being studied becomes less effective. This is what causes the failure of social studies learning in schools (Chandler \& McKnight, 2009; Wright-Maley, 2015; Zins, Bloodworth, Weissberg, \& Walberg, 2007).

Social studies learning must be sought and packaged in such a way that it is interesting to be able to feel the benefits (Heafner, 2004; Thornton, 2005). Teachers must be able to make social studies subjects into fun lessons (learning is fun) in social studies must be able to be created by the teacher in providing material in the teaching and learning process provided. In teaching, an IPS subject teacher must be able to cultivate a high level of confidence in students, able to convince students that the material in social studies also has great benefits such as other subjects (Ashman \& Gillies, 2003; Kumashiro, 2015). Thus students in learning social studies subjects not only get value, but really students will get a lot of benefits in learning social studies. Teachers must find the best way to achieve learning goals. For example in the presentation of material the teacher must look for the best teaching strategies and models, suitable method and media will make students interested in taking the social studies given. Besides that, the curiosity of the meaning and content of the lesson is more possessed by students if a teacher is able to act as a motivator (motivator) that can foster high selfconfidence in students towards social studies.

What happens in the field is not all of the above can be applied by the teacher, as the results of preliminary observations conducted by researchers, in social studies learning students are only introduced to the facts of social studies that focus on knowledge (cognitive) only. So the desire to learn that is in students in social studies is only learning to memorize the facts and understanding and interpretation that are not developing as expected.

Social studies learning must be able to develop aspects of knowledge and understanding, aspects of attitudes and values (attitude and values) and aspects of skills (skills) in students. Aspects of knowledge and understanding are related to the world and the lives of surrounding communities, attitude aspects are related to provision of provisions on the basis of ethics and norms which later become value orientations in life in society, while aspects of skills include social skills and intellectual skills. ) so that students are responsive to social problems and are able to work together with others in their daily lives Jarolimek (2012). Therefore, ideally social studies learning in elementary schools is carried out by facilitating and conditioning students learning based on the real world of children, commonly known as contextual learning. Learning starts from the things that are closest and directly related to students' daily lives.

In connection with the above problems, it can be affirmed that efforts to improve the learning process through efforts to select the right and innovative learning models in social studies learning at the elementary level are a very important need to be done. One learning model that is thought to be used to improve the quality of the process and learning outcomes is the problem based learning model. Problem Based Learning is a set of teaching models that use problems as a focus for developing problemsolving skills, material, and self-regulation (Egen \& Kauchak, 2012; Hmelo-Silver, 2004; Macdonald, 2005). According to Savery, Jr. (Savery, 2006), Problem-based learning (PBL) is an instructional approach that has been used successfully for over 30 years and continues to gain acceptance in multiple disciplines. It is instructional (and curricular) learner-centered approach that empowers learners to conduct research, integrate theory and practice, and apply knowledge and skills to develop a viable solution to a defined problem. This overview presents a brief 
history, followed by an discussion of the similarities and differences between PBL and other experiential approaches to teaching, and identifies that lie ahead for PBL. In the Sanson-Fisher article R. W, et .all (2005), states that the problem-based learning method (PBL) has been widely adopted by undergraduate medical schools, although empirical reviews indicate that its effectiveness may be limited, but students claim that PBL provides learning experiences that are more satisfying than traditional method.

PBL is a learning process that uses real world problems as a context for students to learn about critical thinking and problem solving skills, and to acquire essential knowledge and concepts from subject matter. PBL is a learning based on cognitive theory which includes constructivism learning theory. According to constructivism theory, thinking and solving skills can be developed if students do themselves, discover, and enable the complexity of existing knowledge.

Anita Woolfolk (2016) said: The goals of problem-based learning are to help students develop flexible knowledge that can be applied in many settings, in contrast to inert knowledge. Other goals of problem-based learning are to enhance intrinsic motivation and skills in problem solving, collaboration, and self-directed lifelong learning. According to Arends (2008), the steps in implementing PBL are 5 phases, namely (1) orienting students to problems; (2) organizing students to research; (3) assist independent investigations and consultations; developing and presenting works; (5) analyze and evaluate the problem solving process. The reasons for choosing this learning model are based on several research findings conducted by several researchers, including research conducted by Lohman (2000), conducting research on the influence of group size in PBM on problem-solving skills, self-direction and technical knowledge. The results of his research state that to promote the development of students' problem solving skills the findings suggest that PBL needs to be used in a long term period of time. PBL exposure to students will provide students with more opportunities to experience and practice key aspects of the problem solving process.

Research on the influence of PBL learning method was also carried out by Abdul Bashith (2017) on 11th grade students at SMAN 6 Malang, the results showed that PBL learning models influenced students' critical thinking skills and learning outcomes at SMAN 6 Malang. This research is also supported by the results of Sumitro (2017) research which concluded that the application of PBL learning method can increase the motivation and learning outcomes of social studies in the fourth grade at SD Bangkala III Makassar Inpres. Kenneth J. Oja (2011), in the results of his research states that there is a positive relationship between the application of PBL to critical thinking skills of nursing students, but needs to be tightened in the use of PBL to evaluate critical thinking. So that it can be stated that PBL is one of the alternative teaching models that can be applied to improve student learning outcomes.

\section{METHOD}

This study uses an experimental method involving two sample groups, namely students who study with problem Based learning learning method and students who learn with Conventional Learning Method. Thus, it is expected that this research method can be compared between the same two study groups. The results of these comparisons can provide evidence of functional relationships between other variables that can be controlled by experimental conditions so that independent variables can be manipulated directly to ensure their influence on the dependent variable.

This study involves two independent variables and one bound. The first independent variable is the manipulated variable, also called the experimental variable, which is the learning method, while the second independent variable called the 
attribute variable is logical thinking. While one dependent variable is the results of student social studies. To obtain a more precise analysis, all of these variables, including attribute variables, are included in the research design. This is consistent with what Fraenkel and Wallen (2011) did, that entering attribute variables into factorial design will not only improve experimental skills but will also increase the ability to generalize the results of these experiments, because it can determine whether the treatment has comparable effects in all level or not, the ability to generalize the results.

The research design used in this study is a factorial $2 \times 2$ design, which can be visually seen in the following figure. As seen in the design, the experimental variable is the learning method that is the group of students managed in Problem Based Learning and conventionally managed groups. While the attribute variable is the level of logical thinking which is also categorized in two levels, namely groups that have a high level of logical thinking and groups that have a low level of logical thinking.

Table 1. Factorial $2 \times 2$ Research Design Learning Method

\begin{tabular}{lll}
$\begin{array}{l}\text { Learning Method } \\
\text { Logical Thinking }\end{array}$ & $\begin{array}{l}\text { PBL } \\
\text { (A1) }\end{array}$ & $\begin{array}{l}\text { Conventional } \\
\text { (A2) }\end{array}$ \\
\hline Heigh (B1) & $\mathrm{A}_{1} \mathrm{~B}_{1}$ & $\mathrm{~A}_{2} \mathrm{~B}_{1}$ \\
Low (B2) & $\mathrm{A}_{1} \mathrm{~B}_{2}$ & $\mathrm{~A}_{2} \mathrm{~B}_{2}$ \\
\hline
\end{tabular}

This research was conducted at MIN Ciputat, in the even semester 2018. The study population was all class VI from class VI A VI G, with total 60 students. Determination of sample quality of students' level of logical thinking was done using the opinion of Fraenkel (1990), namely 20\% of all samples in each class that has logical thinking. After measuring the level of logical thinking of students, then taken as much as $20 \%$ of each classification and obtained for the VIF class as many as $20 \%$ of students who have a high level of logical thinking and $20 \%$ of students who have a low level of confidence. And the VIG class is $20 \%$ of students who have a high level of logical thinking and $20 \%$ of students who have a low level of logical thinking.

\section{RESULT AND DISCUSSION}

The research data are grouped into eight data groups, namely: (1) Social studies learning outcomes of students studying with the PBL (A1) method, (2) Social studies learning outcomes scores of students studying with conventional method (A2), (3) Result scores Social studies learning students who have a high level of logical thinking (B1), (4) Social studies learning outcomes scores of students who have a low level of logical thinking (B2), (5) Social studies learning outcomes scores of students who have a high level of logical thinking and learning with the PBL method (A1B1), (6) Social studies learning outcomes scores of students who have a high level of logical thinking and learning with conventional method (A2B1), (7) Social studies learning outcomes scores of students who have a low level of logical thinking and learning with the PBL method (A1B2), (8) Social studies learning outcomes scores of students who have a low level of logical thinking and learning with conventional method (A2B2).

Testing the hypothesis in this study was carried out using a two-way analysis of variance and followed by a tukey test, if there were interactions in the test. Two-way variance analysis is used to test the main effect and interaction effect between learning method and logical thinking on students' Social Sciences learning outcomes scores. By using a two-path anava table the results are obtained as in table 3 . 
Sita Ratnaningsih, M. Syarif Sumantri, Nurjanah, Erry Utomo: Enhancing Elementary Students' '.. | 101

Table 2. Recapitulation of Scores of Social Sciences Learning Outcomes of Students in All Groups

\begin{tabular}{|c|c|c|c|c|c|c|c|c|c|}
\hline B ${ }^{A}$ & \multicolumn{3}{|c|}{$\mathbf{A}_{1}$} & \multicolumn{3}{|c|}{$\mathbf{A}_{2}$} & \multicolumn{3}{|c|}{ Totally } \\
\hline \multirow{7}{*}{$\mathrm{B}_{1}$} & $\Sigma Y_{11}$ & $=$ & 182 & $\Sigma Y_{21}$ & $=$ & 116 & $\Sigma Y_{\mathrm{B} 1}$ & $=$ & 298 \\
\hline & $\mathrm{n}_{11}$ & $=$ & 6 & $\mathrm{n}_{21}$ & $=$ & 6 & $\mathrm{n}_{\mathrm{B} 1}$ & $=$ & 12 \\
\hline & $\bar{Y}_{11}$ & $=$ & 30,33 & $\bar{Y}_{21}$ & $=$ & 19,33 & $\bar{Y}_{\mathrm{B} 1}$ & $=$ & 24,83 \\
\hline & $\Sigma Y_{11}^{2}$ & $=$ & 5550 & $\Sigma Y_{21}^{2}$ & $=$ & 2274 & $\Sigma \mathrm{Y}_{\mathrm{B} 1}^{2}$ & $=$ & 7824 \\
\hline & $\left(\Sigma \mathrm{Y}_{11}\right)^{2}$ & $=$ & 33124 & $\left(\Sigma \mathrm{Y}_{21}\right)^{2}$ & $=$ & 13456 & $\left(\Sigma \mathrm{Y}_{\mathrm{B} 1}\right)^{2}$ & $=$ & 88804 \\
\hline & $\mathrm{S}_{11}^{2}$ & $=$ & 5,87 & $\mathrm{~S}_{21}^{2}$ & $=$ & 6,27 & $\mathrm{~S}_{\mathrm{B} 1}^{2}$ & $=$ & 38,52 \\
\hline & $\mathrm{S}_{11}$ & $=$ & 2,42 & $\mathrm{~S}_{21}$ & $=$ & 2,50 & $\mathrm{~S}_{\mathrm{B} 1}$ & $=$ & 6,21 \\
\hline $\mathrm{B}$ & \multicolumn{3}{|c|}{$\mathbf{A}_{1}$} & \multicolumn{3}{|c|}{$\mathbf{A}_{2}$} & \multicolumn{3}{|c|}{ Totally } \\
\hline \multirow{6}{*}{$\mathrm{B}_{2}$} & $\Sigma Y_{12}$ & $=$ & 117 & $\Sigma Y_{22}$ & $=$ & 154 & $\Sigma Y_{\mathrm{B} 2}$ & $=$ & 271 \\
\hline & $\mathrm{n}_{12}$ & $=$ & 6 & $\mathrm{n}_{22}$ & $=$ & 6 & $\mathrm{n}_{\mathrm{B} 2}$ & $=$ & 12 \\
\hline & $\bar{Y}_{12}$ & $=$ & 19,50 & $\bar{Y}_{22}$ & $=$ & 25,67 & $\bar{Y}_{\mathrm{B} 2}$ & $=$ & 22,58 \\
\hline & $\begin{array}{l}\Sigma \mathrm{Y}_{12}^{2} \\
\left(\Sigma \mathrm{Y}_{12}\right)^{2}\end{array}$ & $\begin{array}{l}= \\
=\end{array}$ & $\begin{array}{l}2309 \\
13689\end{array}$ & $\begin{array}{l}\Sigma \mathrm{Y}_{22}^{2} \\
\left(\Sigma \mathrm{Y}_{22}\right)^{2}\end{array}$ & $\begin{array}{l}= \\
=\end{array}$ & $\begin{array}{l}3988 \\
23716\end{array}$ & $\begin{array}{l}\Sigma \mathrm{Y}_{\mathrm{B} 2}^{2} \\
\left(\Sigma \mathrm{Y}_{\mathrm{B} 2}\right)^{2}\end{array}$ & & $\begin{array}{l}6297 \\
73441\end{array}$ \\
\hline & $\mathrm{S}_{12}^{2}$ & $=$ & 5,50 & $\mathrm{~S}_{22}^{2}$ & $=$ & 7,07 & $\mathrm{~S}_{\mathrm{B} 2}^{2}$ & $=$ & 16,08 \\
\hline & $\mathrm{S}_{12}$ & $=$ & 2,35 & $\mathrm{~S}_{22}$ & $=$ & 2,66 & $\mathrm{~S}_{\mathrm{B} 2}$ & $=$ & 4,01 \\
\hline \multirow{7}{*}{ Totally } & $\Sigma \mathrm{Y}_{\mathrm{A} 1}$ & $=$ & 299 & $\Sigma \mathrm{Y}_{\mathrm{A} 2}$ & $=$ & 270 & $\Sigma \mathrm{Y}_{\mathrm{T}}$ & $=$ & 569 \\
\hline & $\mathrm{n}_{\mathrm{A} 1}$ & $=$ & 12 & $\mathrm{n}_{\mathrm{A} 2}$ & $=$ & 12 & $\mathrm{n}_{\mathrm{T}}$ & $=$ & 24 \\
\hline & $\bar{Y}_{\mathrm{A} 1}$ & $=$ & 24,92 & $\bar{Y}_{\mathrm{A} 2}$ & $=$ & 22,50 & $\Sigma \mathrm{Y}_{\mathrm{T}}^{2}$ & $=$ & 14121 \\
\hline & $\Sigma \mathrm{Y}_{\mathrm{A} 1}^{2}$ & $=$ & 7859 & $\Sigma \mathrm{Y}_{\mathrm{A} 2}^{2}$ & $=$ & 6262 & $\left(\Sigma Y_{\mathrm{T}}\right)^{2}$ & $=$ & 323761 \\
\hline & $\left(\Sigma \mathrm{Y}_{\mathrm{A} 1}\right)^{2}$ & $=$ & 89401 & $\left(\Sigma \mathrm{Y}_{\mathrm{A} 2}\right)^{2}$ & $=$ & 72900 & & & \\
\hline & $\mathrm{S}_{\mathrm{A} 1}^{2}$ & $=$ & 37,17 & $\mathrm{~S}_{\mathrm{A} 2}^{2}$ & $=$ & 17,00 & & & \\
\hline & $\mathrm{S}_{\mathrm{A} 1}$ & $=$ & 6,10 & $\mathrm{~S}_{\mathrm{A} 2}$ & $=$ & 4,12 & & & \\
\hline
\end{tabular}

Table 3. Results of SPSS Two Path Variance Analysis Tests of Subjects Effects

Dependent Variable: Social Field Learning Outcome

\begin{tabular}{llllll}
\hline Source & $\begin{array}{l}\text { Type III Sum of } \\
\text { Squares }\end{array}$ & df & Mean Square & F & Sig. \\
Corrected Model & $507,458(\mathrm{a})$ & 3 & 169,153 & 27,393 &, 000 \\
Intercept & 13490,042 & 1 & 13490,042 & 2184,622 &, 000 \\
A & 35,042 & 1 & 35,042 & 5,665 &, 027 \\
B & 30,375 & 1 & 30,375 & 4,919 &, 038 \\
A * B & 442,042 & 1 & 442,042 & 71,526 &, 000 \\
Error & 123,500 & 20 & 6,175 & & \\
Total & 14121,000 & 24 & & & \\
Corrected Total & 630,958 & 23 & & & \\
\hline
\end{tabular}

a R Squared $=, 804$ (Adjusted R Squared $=, 775$ )

Based on the results of the analysis of variance (ANAVA) of the two lines above, it can be explained as follows:

Differences in Social Studies Learning Outcomes Between Groups of Students Learning with the PBL Method and Groups of Students Learning with Conventional Method

Based on the results of the analysis of two-way variance at a significant level $\alpha=$
0.05, obtained Fcount $=5.665$ and Ftable $(0.05 ; 1: 20)=4.35$. Based on the value of Sig. in the Tests of Between-Subjects Effects table for line A provided that if it is less than 0.05 then the test results are significant or $\mathrm{H} 0$ is rejected. In table 4.12, it can be seen that the value of Sig. for row A is 0.027 ; less than 0.05 then $\mathrm{H} 0$ is rejected so $\mathrm{H} 1$ is accepted. It can be concluded that there are differences in social studies learning outcomes between groups of students who study with the PBL 
method and groups of students who study with significant conventional method. In other words, the PBL learning method ( $\bar{Y} A 1=$ 24.92) is higher than the conventional learning method $(\bar{Y} A 2=22.50)$. This means the research hypothesis which states that social studies learning outcomes of students who study with the PBL method are higher than the results of social studies learning students who study with conventional method can be accepted.

Differences in Social Studies Learning Outcomes of Students and Learning with PBL Method and Students and Learning with Conventional Method in Groups of Students with High Logical Thinking Levels

Students who have a high level of logical thinking have an influence on social studies learning scores with the learning method. This is proven by the results of further tests using the Tukey test whose results are as follows:

Table 4. Comparison of Groups A1B1 with A2B1

\begin{tabular}{|c|c|c|c|c|}
\hline No & $\begin{array}{l}\text { Group Compared } \\
\text { to }\end{array}$ & Dk & $\mathbf{Q}_{\text {count }}$ & $\begin{array}{l}Q_{\text {table }} \\
\alpha=0,05\end{array}$ \\
\hline 1 & $\mathrm{~A}_{1} \mathrm{~B}_{1}$ with $\mathrm{A}_{2} \mathrm{~B}_{1}$ & $\begin{array}{l}4 \\
6\end{array}$ & $10,89 * *$ & 4,90 \\
\hline
\end{tabular}

Information:

$* *=$ Significant

Social studies learning outcomes scores of students who have a high level of logical thinking and learning with the PBL method (A1B1) compared with the score of social studies learning outcomes of students who have a high level of logical thinking and learning with conventional method (A2B1), obtained $\mathrm{Q}=10.89$ and Qtable $(0.05 ; 4: 6)=$ 4.90. Thus Qcount is greater than Qtable, so that $\mathrm{HO}$ is rejected, it can be interpreted that there are differences in scores of students' Social Studies learning outcomes that have a significantly high level of logical thinking between PBL learning method and conventional learning method. In other words, students who had a high level of logical thinking and learning with the PBL method
$(\bar{Y} \mathrm{~A} 1 \mathrm{~B} 1=30.33)$ were higher than those who had a high level of logical thinking and learning with the conventional method (Y)A2B1 $=19.33$ ) on Social Sciences learning outcomes scores. Thus the research hypothesis which states that social studies learning outcomes of students who have a high level of logical thinking and learning with the PBL method are higher than social studies learning outcomes of students who have a high level of logical thinking and learning with conventional method can be accepted.

Differences in Social Studies Learning Outcomes Students who study with the PBL Method and Students Learning with Conventional Method in Groups of Students with Low Logical Thinking Levels.

Students who have a low level of logical thinking have an influence on social studies learning scores with the learning method. This is proven by the results of further tests using the Tukey test whose results are as followsTable 5.

Table 5. Comparison of A1B2 Groups with A2B2

\begin{tabular}{|c|c|c|c|c|}
\hline No & $\begin{array}{l}\text { Group Compared } \\
\text { to }\end{array}$ & dk & $\mathbf{Q}_{\text {count }}$ & $\begin{array}{l}Q_{\text {table }} \\
\alpha=0,05\end{array}$ \\
\hline 2 & $\mathrm{~A}_{1} \mathrm{~B}_{2}$ with $\mathrm{A}_{2} \mathrm{~B}_{2}$ & $\begin{array}{l}4 \\
6\end{array}$ & $6,11 * *$ & 4,90 \\
\hline
\end{tabular}

Information:

** = significance

Social studies learning outcomes scores of students who have a low level of logical thinking and learning with the PBL method (A1B2) are compared with the score of social studies learning outcomes of students who have a low level of logical thinking and learning using conventional method (A2B2), obtained Q $=6.11$ and Qtable $(0.05 ; 4: 6)=4.90$. Thus Qcount is greater than Qtable, so that $\mathrm{H} 0$ is rejected, it can be interpreted that there are differences in scores of Social Studies learning outcomes of students who have a significantly lower level of logical thinking between PBL learning method and conventional learning method. In other words, students who have a low level of 
logical thinking and learning with the PBL method $(\bar{Y} A 1 B 2=19.50)$ are lower than those who have a low level of logical thinking and learning with the conventional method $(\bar{Y} A 2 B 2=25.67)$ on the Social Studies learning score. Thus the research hypothesis which states that social studies learning outcomes of students who have a low level of logical thinking and learning with the PBL method are lower than students who have a low level of logical thinking and learning with conventional method can be accepted.

\section{Interactions Between Learning Method and Logical Thinking Against Scores of Student Social Studies Learning Outcomes}

Based on the results of the analysis of two-way variance about the interaction between learning method and logical thinking on the scores of students' social studies learning seen in the two-lane anava calculation table above, that the price of the calculated $\mathrm{F}=71.526$ and Ftable $(0.05 ; 1: 20)$ $=4,35$. Based on the value of Sig. in the Tests of Between-Subjects Effects table for line $\mathrm{A} * \mathrm{~B}$ with the condition that if it is less than 0.05 then the test results are significant or H0 is rejected. In Table 3, it can be seen that the Sig. for row A* B is 0,000 ; less than 0.05 then $\mathrm{H} 0$ is rejected so $\mathrm{H} 1$ is accepted. The conclusion is that there is an interaction between learning method and logical thinking on students' social studies learning outcomes. By testing the interaction, then further testing is needed. The further test is intended to find out about: (1) differences in scores on social studies learning outcomes of students who study with the PBL method and those who study with conventional method for groups of students who have a high level of logical thinking (A1B1 and A2B1); and (2) differences in scores on Social Studies learning outcomes of students who study with the PBL method and who study with the conventional method for groups of students who have a low level of logical thinking (A1B2 and A2B2). The summary of the results of further tests with Tukey test for 2 groups of data compared can be seen in table 6.
Table 6. Summary of Tukey Test Calculation Results

\begin{tabular}{|c|c|c|c|c|}
\hline No & $\begin{array}{l}\text { Group Compared } \\
\text { to }\end{array}$ & Dk & $\mathbf{Q}_{\text {count }}$ & $\begin{array}{l}Q_{\text {table }} \\
\alpha=0,05\end{array}$ \\
\hline 1 & $\mathrm{~A}_{1} \mathrm{~B}_{1}$ with $\mathrm{A}_{2} \mathrm{~B}_{1}$ & & $\begin{array}{l}10,89 \\
* *\end{array}$ & 4,90 \\
\hline 2 & $\mathrm{~A}_{1} \mathrm{~B}_{2}$ with $\mathrm{A}_{2} \mathrm{~B}_{2}$ & & $6,11 * *$ & 4,90 \\
\hline
\end{tabular}

Information:

$* *=$ significant

From the results of the research stated above, the following discussion is carried out. The difference in social studies learning outcomes between students who get PBL learning method and students who get conventional learning method. From the testing of the first hypothesis, it was found that there were differences between social studies learning outcomes of students who were given PBL learning method and social studies learning outcomes of students who were given conventional learning method. These results indicate that social studies learning outcomes of students who were given PBL learning method were higher than those of social studies students who were given conventional learning method. As supported by a study conducted by Kay N. Drake (Drake \& Long, 2009) in grade 4 elementary school students, who provide PBL learning in the field of science compared to related groups who are given direct instruction in thematic formats, the results of their research state that students' knowledge of content, images scientist stereotypes, time in doing assignments, and transfer of problem solving skills, the results are better for students by giving PBL method compared to giving direct instruction to students.

The results of the study from Ozlem Koray(2013), about the effectiveness of Problem Based Learning (PBL) in the context of liquids and gases, were conducted in 54 students in two eighth grade public secondary schools in Turkey, one of these classes randomly assigned as an experimental group and instructed through PBL, while other classes were assigned as a control group and instructed through traditionally designed instructions. To measure students' reasoning abilities, Logical Thinking Tests were used as 
pre and post tests in the control and experimental groups. The results of the independent t-test showed that students in the PBL class had higher mean scores on reasoning abilities than students from the control group.

Research on the effectiveness of the PBL learning method was then carried out by Sumantri(2014), through a study entitled: the effect of learning strategies and self-concepts on environmental learning outcomes in recycling waste areas in public elementary schools, SDN 1 Tugu Selatan, North Jakarta. The results of the study indicate that students with PBL learning method have a higher score than the scores of students taught by expository learning method. Similar research was carried out by Willem S. de Grave(2001), in medical students, indicating that the discussion process carried out by students in the PBL learning process was better than the group that did not conduct discussions. These findings are reinforced by Permatasari's (2019)study, which examined the effect of Problem Based Learning and interest in learning in improving cognitive learning outcomes in social science fourth grade elementary students. Quasi-experimental research with the design of the control group pre-test and post-test also found similar results with previous studies. Research on PBL effectiveness was also carried out by Enarson, C., \& Cariaga-Lo, L.(2001), on the United States Medical Medical Student License Examination, for students given learning processes in problem-based learning curriculum and traditional lectures over a seven-year period (1992-98) to evaluate the effectiveness of each curriculum in supporting students learning basic and clinical sciences. The results are stated that problem-based learning can provide students with the knowledge needed for the next phase of their medical education, and is highly recommended in the learning curriculum to provide PBL learning processes. The success of PBL learning must be supported by various facilities such as the findings of the study by Dimitra Kokotsaki, et.all (2016), which stated that the success of Problem Based Learning must be supported by modern digital technology, high quality group processes, the ability of teachers to effectively design student learning and providing guidance and support, the balance between didactic teaching and the method of in-depth inquiry and harmonious judgment.

While conventional learning strategies tend to emphasize the delivery of information sourced from the teacher by using command techniques, and demonstrations, In conventional learning strategies, students not only receive information from the teacher, but students receive responses and apply a generalization to gain a clearer understanding. The results of Vogel's research, et al. (2011) support the above explanation that conventional method have less influence on vocabulary learning in language than method that better support student activity. Similar things were also found in Saleem's (Aziz et al., 2014) study, which was conducted on a number of 122 students, randomly selected from the Department of Physics, College of Education in Iraq. This study revealed that there was no significant difference between PBL and PBL with the lecture method, so PBL without or with the lecture method improved independent learning skills better than conventional teaching method. If conventional teaching method are compared to PBL learning processes, PBL is not the only successful strategy to achieve effective learning from unstructured and complex domains. However, the results of PBL metaanalyzes that were synthesized qualitatively for preparation for the workplace showed that PBL was significantly more effective than conventional instruction for training competent and skilled practitioners (Strobel \& van Barneveld, 2009).

From the testing of the second hypothesis, it was found that there was a difference between social studies learning outcomes of students who were given PBL learning method that had a high level of logical thinking with social studies learning outcomes of students who were given conventional learning method. These results 
indicate that social studies learning outcomes of students who were given the PBL learning method that had a high level of logical thinking were higher than the results of social studies learning students who were given conventional learning method that had a high level of logical thinking. Based on these differences, it can be explained that in the learning process with PBL learning method, students not only receive instructions from the teacher, but also can provide responses through answers or applying assignments given by the teacher. This is supported by the results of research conducted by Orhan, A (Akınoğlu \& Tandoğan, 2007)

in knowing the effects of problembased active learning in science education on academic achievement and student learning concepts. The research study was conducted on 50 students, 7 th grade students in public schools in Istanbul. The findings of the study state that the application of problem-based active learning models has positively influenced students' academic performance and their attitudes towards science subjects and influenced student conceptual development positively, in students who have high intelligence. In line with the findings of Novita (2018), which was conducted on social studies teachers and students MTs Al Musyawarah Lembang, consisted of 42 students. The results of the study show that in general for students who have learning achievements above the average, the application of the PBL model can increase students' sense of responsibility and improve their learning achievement.

The above is also in line with the findings of Nayank (2018), in his research on a number of 70 students in the fourth grade of elementary school, which stated that PBL model learning worksheets were feasible to use and also effective in improving students' critical thinking skills. Likewise with the findings of Siew's research (Siew, Mapeala, Mapeala, \& Mapeala, 2016), a number of 270 class V students (aged 11 years) from three elementary schools in Tawau, Sabah, Malaysia. The findings show that thinking maps, which are explicitly given in problembased learning processes are very effective in increasing critical thinking among fifth grade students in science lessons.

From the testing of the third hypothesis, the results of the study showed that the social studies learning outcomes of students who had a low level of logical thinking and learning with the PBL method were lower than students who had a low level of logical thinking and learning with conventional method. This finding shows that the characteristics of each student in a study group are very diverse. Students who lack the level of logical thinking feel they are more afraid to ask questions and are afraid to make mistakes, so the material they do not understand does not dare to ask the teacher, thus making them lack of learning outcomes. This is supported by the results of Didem's research (Didem \& et.all, 2010.), regarding the impact of problem-based learning method used in science and technology teaching at the level of construction of elementary school students for concepts on the theme "Systems in Our Body". The results of this study state that in students who have a low level of thinking ability in the provision of PBL learning method must require the help of teachers in obtaining maximum learning outcomes for students in elementary schools. This is almost the same as the results of a study conducted by Charles T. Wynn Sr. (2014), the results showed that students who were taught with PBL and had high levels of postformal thinking, involvement, and perceived relevance of content, obtained higher learning outcomes when compared with students who have a low level of logical thinking.

From the testing of the fourth hypothesis the results show that there is an interaction between learning method and logical thinking on the results of students' social studies. These results indicate that there is an interaction between students 'social studies learning outcomes, PBL learning method and conventional learning method and students' logical thinking levels. This can be 
seen in the test of differences in the two groups. In other words, the two groups did not have a significant difference, or in both ways they gave relatively good results. Based on these differences, it can be explained that conventional learning method cannot be left behind in the learning process. This is because conventional learning method provide two main advantages, namely in terms of time and supervision. Through conventional learning method the material can be quickly delivered and accepted by students. More than that this method is relatively necessary in learning which is followed by a large number of students. This is supported by the results of the study of Nidya(2018) which examined the effectiveness of the Scientific Approach in teaching writing skills carried out on class VIII Redion School. They are class 8B who use the Scientific Approach as an experimental group, while the 8D class becomes a control group that uses a conventional approach. The results are as follows: there are significant differences in writing achievement among students taught using a scientific approach and conventional approaches, in general the use of scientific approaches is more effective than conventional approaches in teaching and the ability to write, under certain conditions conventional approaches produce proficiency in writing students better.

Similar research on conventional method approaches was also conducted by Faiza (2014) about the behavior and practice of science class teachers in providing opportunities for students to create knowledge through reasoning and logic. The study was conducted on a number of 32 science teachers from New Delhi, India. The main findings reveal that in New Delhi, science teachers use a constructivist approach to science teaching at the secondary level but for some topics they use a conventional approach. For some topics, the teacher uses group activities and for several individuals, according to the nature of the topic of science teachers in New Delhi using a conventional approach to learning.
A similar study was conducted by Yap Wei Li(2016), which discussed the difficulties or challenges faced by higher education institutions in an effort to improve student learning outcomes and also further investigate the impact of student-centered teaching. This case study was conducted at INTI International University, Malaysia. This study compares conventional teaching with multimedia learning and also online learning in terms of its implications for student understanding and student motivation through the use of pre-tests / post-tests, surveys and student comments. The study adopted the Weimer's Learner-Centered Teaching model which discussed key strategies to help educational institutions to achieve such transformation in a more systematic approach by having clear guidelines for teachers. The results of the study found that in a better learning process multimedia learning is needed, and also online learning, but in all the learning processes given to students, conventional learning method are needed to achieve maximum understanding of material and learning outcomes by the students learners. Besides this, the full support of the teacher to master the PBL learning process was also stated in the results of the Etmer.P research. (2006), who gave advice to teachers with the following things: 1) creating a culture of collaboration and interdependence with students, 2) adjusting to changing roles in students' problems, and 3) improving learning and student performance. By supporting these things, more teachers will better recognize the potential of PBL as an effective teaching approach to develop students as flexible thinkers and successful problem solvers?

\section{CONCLUSION AND RECOMMENDATION}

Based on the results of hypothesis testing and discussion of the results of this study can be summarized as follows: First, the learning method influences students' social studies learning outcomes at the elementary school level. Hypothesis test results conclude that there are significant differences in social 
studies learning outcomes of grade VI elementary school students who are given PBL learning strategies and those given conventional learning method. In fact, generally the results of social studies learning of students who are given PBL learning strategies are higher than the results of social studies learning given conventional learning method. This conclusion explains that by ignoring the different levels of logical thinking, students who are given PBL learning method will be better and more effective in learning than students given conventional learning method.

Second, there is a significant difference in social studies learning outcomes of sixth grade elementary school students who have high logical thinking who are given PBL learning method with students given conventional learning method. Social studies learning outcomes of students who have high logical thinking are higher results when given PBL learning method rather than given conventional learning method. Thus the application of PBL learning method will be more effectively given to students if they have a high level of logical thinking.

Third, there is no significant difference between social studies learning outcomes of elementary school students in grade VI who have low levels of thinking when given PBL learning method with students given conventional learning method, differences in social studies learning outcomes of students who have low logical thinking levels are very small if given PBL learning method with conventional learning method. Thus PBL learning strategies and conventional learning method in improving students' social studies learning outcomes, both of which can be applied to students who have low logical thinking.

Fourth, there is a significant interaction between learning method and logical thinking on the results of social studies learning in sixth grade students of elementary school. This means that the level of logical thinking influences the provision of learning method. Overall, students who have a high level of logical thinking are both given PBL learning method and conventional learning method, and their learning outcomes will be higher compared to students who have a low level of logical thinking. In accordance with the findings above, it can be concluded as follows: (1) overall the PBL learning method is more optimal in achieving social studies learning outcomes of class VI students than the conventional learning method. (2) Social studies learning outcomes of students who have a high level of logical thinking will be optimal if given the PBL learning method. (3) otherwise conventional learning method are less optimal in achieving social studies learning outcomes of students who have a high level of logical thinking. Thus it can be affirmed that to achieve optimal social studies learning outcomes need to be done by choosing the right and continuous learning method by paying attention to the level of students' logical thinking.

Based on the findings and results of the research presented in the conclusions above, this can provide recommendations on the following: efforts to improve social studies learning outcomes of sixth grade elementary school students, the finding that social studies learning outcomes of students who were given PBL learning method were higher than those of students who were given conventional learning method had implications especially regarding the provision of appropriate learning method. Efforts in selecting learning method, in this study found there was an interaction between learning method and the level of logical thinking influence on the level of logical thinking of class VI elementary school students. This interaction has several implications. First, giving the same learning method to all students without considering the level of logical thinking of students is a bad thing for students. This is because in the group of students who have a high level of logical thinking, the provision of PBL learning method gives students higher social studies learning outcomes than the group of students given conventional method. Likewise, the provision of learning method 
without considering the level of logical thinking students can benefit students in certain groups and can harm students in other groups. Second, even though the level of logical thinking of students has been considered, the application of inappropriate learning method will have an impact on students' social studies learning outcomes.

Efforts for educators or elementary school teachers, as facilitators, motivators, and evaluators in teaching and learning activities must really pay attention to students individually especially regarding the level of logical thinking of students and choosing the right method. Thus the right learning method in improving students 'social studies learning outcomes is when applying learning method still pay attention to the level of students' logical thinking. This indicates that, the accuracy of a learning method is closely related to the level of logical thinking of students. In this finding, it means that the level of students 'logical thinking has an effect on the experimental treatment, namely the learning method through PBL learning method and conventional learning method, the effect of which further influences students' social studies learning outcomes. In additi on, the important finding of this study is also to explain that the accuracy of the learning method is closely related to the characteristics of students who take part in the teaching and learning process which is also the subject of research.

\section{REFERENCES}

Akınoğlu, O., \& Tandoğan, R. Ö. (2007). The Effects of Problem-Based Active Learning in Science Education on Students' Academic Achievement, Attitude and Concept Learning. Eurasia Journal of Mathematics, Science and Technology Education, 3(1), 71-81. https://doi.org/10.12973/ejmste/75375

Altaf, F., Abraham, J., \& Aziz, T. (2014). A Study in Teaching of Science: Conventional Pedagogies at Secondary Stage. International
Journal of Research (IJR) Vol-1, Issue-4, ISSN 2348-6848, 1, 494-501.

Arends, R. I. (2008). Belajar untuk mengajar. (Terjemahan Helly Prajitno Soetjipto \& Sri Mulyantini Soetjipto). New York: McGraw Hills.

Ashman, A., \& Gillies, R. (2003). Cooperative learning: The social and intellectual outcomes of learning in groups. Routledge.

Aziz, M. S., Zain, A. N. M., Samsudin, M. A. B., \& Saleh, S. B. (2014). The Effects of Problem-Based Learning on SelfDirected Learning Skills among Physics Undergraduates. International Journal of Academic Research in Progressive Education and Development, 3(1), 126-137.

Bashith, A., \& Amin, S. (2017). The Effect of Problem Based Learning on EFL Students' Critical Thinking Skill and Learning Outcome. Al-Ta Lim Journal, 24(2), 93-102. https://doi.org/10.15548/jt.v0i0.271

Chandler, P., \& McKnight, D. (2009). The Failure of Social Education in the United States: A Critique of Teaching the National Story from" White" Colourblind Eyes. Journal for Critical Education Policy Studies (JCEPS), 7(2).

de Grave, W. S., Schmidt, H. G., \& Boshuizen, H. P. A. (2001). Effects of problem-based discussion on studying a subsequent text: A randomized trial among first year medical students. Instructional Science, 29(1), 33-44. https://doi.org/10.1023/A:1026571615 672

Didem, I., \& et.all. (n.d.). The effects of using problem-based learning in science and technology teaching upon students' academic achievement and levels of structuring concept. Asia-Pacific Forum on Science Learning and Teaching Journal, 11(2), 1-15. 
Drake, K. N., \& Long, D. (2009). Rebecca's in the Dark: A Comparative Study of Problem-Based Learning and Direct Instruction/Experiential Learning in Two 4th-Grade Classrooms. Journal of Elementary Science Education, 21(1), 1-16.

Dyah Permatasari, B., Gunarhadi, G., \& Riyadi, R. (2019). The influence of problem based learning towards social science learning outcomes viewed from learning interest. International Journal of Evaluation and Research in Education (IJERE), 8(1), 39. https://doi.org/10.11591/ijere.v8i1.155 94

Egen, P., \& Kauchak, D. (2012). Strategi dan Pembelajaran. Yogyakarta: Indeks.

Enarson, C., \& Cariaga-Lo, L. (2001). Influence of curriculum type on student performance in the United States Medical Licensing Examination Step 1 and Step 2 exams: Problembased learning vs. lecture-based curriculum. Medical Education, 35, 1050-1055.

https://doi.org/10.1046/j.1365-

2923.2001.01058.x

Fraenkel, J. R., \& Wallen, N. E. (1990). How to Design and Evaluate Research in Education. McGraw-Hill Publishing Company.

Fraenkel, J. R., Wallen, N. E., \& Hyun, H. H. (2011). How to design and evaluate research in education. New York: McGraw-Hill Humanities/Social Sciences/Languages.

Heafner, T. (2004). Using technology to motivate students to learn social studies. Contemporary Issues in Technology and Teacher Education, 4(1), 42-53.

Hmelo-Silver, C. E. (2004). Problem-Based Learning: What and How Do Students Learn? Educational Psychology Review, 16(3), 235-266.
https://doi.org/10.1023/B:EDPR.0000 034022.16470.f3

Indrilla, N., \& Ciptaningrum, D. S. (2018). An approach in teaching writing skills: does it offer a new insight in enhancing students' writing ability. LLT Journal: A Journal on Language and Language Teaching, 21(2), 124133.

Kokotsaki, D., Menzies, V., \& Wiggins, A. (2016). Project-based learning: A review of the literature. Improving Schools, 19(3), 267-277. https://doi.org/10.1177/136548021665 9733

Koray, Ö. C., \& Koray, A. (2013). The Effectiveness of Problem-based Learning Supported with Computer

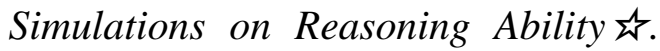
https://doi.org/10.1016/j.sbspro.2013. 12.315

Kumashiro, K. K. (2015). Against common sense: Teaching and learning toward social justice. Routledge.

Li, Y. W. (2016). Transforming Conventional Teaching Classroom to LearnerCentred Teaching Classroom Using Multimedia-Mediated Learning Module. International Journal of Information and Education Technology, 6(2), 105-112. https://doi.org/10.7763/IJIET.2016.V6 .667

Lohman, M. C., \& Finkelstein, M. (2000). Designing groups in problem-based learning to promote problem-solving skill and self-directedness. Instructional Science, 28(4), 291-307. https://doi.org/10.1023/A:1003927228 005

Macdonald, R. (2005). Assessment Strategies For Enquiry and Problem-Based Learning. Handbook of Enquiry \& Problem Based Learning. Sheffield Hallam University. 
Nayank, R. (2018). Development of Problem Based Learning Model Learner Worksheet To Improve Critical Thinking Ability. IOSR Journal of Research \& Method in Education (IOSR-JRME), 8(1), 65-72.

Oja, K. J. (2011). Using Problem-Based Learning in the Clinical Setting to Improve Nursing Students' Critical Thinking: An Evidence Review. Journal of Nursing Education, 50(3), 145-151.

https://doi.org/10.3928/01484834-

20101230-10

Parker, W. (2012). Social studies in elementary education (14th ed). Boston: Pearson.

Sanson-Fisher, R. W., \& Lynagh, M. C. (2005). Problem-based learning: A dissemination success story? The Medical Journal of Australia, 183(5), 258-260.

https://doi.org/10.5694/j.1326-

5377.2005.tb07032.x

Sari, N. (2018). The implementation of project based learning to improve students responsibility in social studies learning. International Journal Pedagogy of Social Studies, 3(2), 1932.

https://doi.org/10.17509/ijposs.v3i2.14 468

Savery, J. R. (2006). Overview of ProblemBased Learning: Definitions and Distinctions. Interdisciplinary Journal of Problem-Based Learning, 1(1), 9$20 . \quad$ https://doi.org/10.7771/15415015.1002

Siew, N. M., Mapeala, R., Mapeala, R., \& Mapeala, R. (2016). The effects of problem-based learning with thinking maps on fifth graders' science critical thinking. Journal of Baltic Science Education, 15(5), Continuous.
Soemantri, N. (2001). Menggagas Pembaharuan Pendidikan IPS. Bandung: Remaja Rosdakarya.

Strobel, J., \& van Barneveld, A. (2009). When Is PBL More Effective? A Meta-Synthesis of Meta-Analyses Comparing PBL to Conventional Classrooms. Interdisciplinary Journal of Problem-Based Learning, 3(1), 4458. $\quad$ https://doi.org/10.7771/15415015.1046

Sumantri, M. S., \& Supendi, . (2014). The influence of learning strategy resolution based toward environmental health learning result observed by students' concept. International Journal of Research Studies in Education, 4(1). https://doi.org/10.5861/ijrse.2014.914

Sumitro, A., Setyosari, P., \& Sumarmi, S. (2017). Penerapan model problem based learning meningkatkan motivasi dan hasil belajar IPS. Jurnal Pendidikan: Teori, Penelitian, dan Pengembangan, 2(9), 1188-1195. https://doi.org/10.17977/jptpp.v2i9.99 36

Thornton, S. J. (2005). Teaching social studies that matters: Curriculum for active learning. Teachers College Press.

Vogel, S., Herron, C., Cole, S. P., \& York, H. (2011). Effectiveness of a Guided Inductive Versus a Deductive Approach on the Learning of Grammar in the Intermediate-Level College French Classroom. Foreign Language Annals, 44(2), 353-380. https://doi.org/10.1111/j.19449720.2011.01133.x

Woolfolk, A. (2016). Educational Psychology: Developing Learners with MyLab Education with Enhanced Pearson eText, Loose-Leaf VersionAccess Card Package (9th Edition). New York: Pearson College Div. 
Wright-Maley, C. (2015). On "stepping back and letting go": The role of control in the success or failure of social studies simulations. Theory \& Research in Social Education, 43(2), 206-243.

Wynn, C. T., Mosholder, R. S., \& Larsen, C. A. (2014). Measuring the Effects of Problem-Based Learning on the Development of Postformal Thinking Skills and Engagement of First-Year Learning Community Students.
Learning Communities: Research \& Practice, 2(2). Retrieved from https://eric.ed.gov/?id=EJ1112494

Zins, J. E., Bloodworth, M. R., Weissberg, R. P., \& Walberg, H. J. (2007). The scientific base linking social and emotional learning to school success. Journal of Educational and Psychological Consultation, 17(2-3), 191-210. 